\title{
Ischaemic colitis secondary to retroperitoneal liposarcoma
}

\author{
Tee Lin Goh 이, ${ }^{1}$ Jozef Lastik, ${ }^{2}$ Rudi Schmigylski, ${ }^{3}$ lain Alexander Murray ${ }^{1}$
}

${ }^{1}$ Department of

Gastroenterology, Dumfries and Galloway Royal Infirmary, Dumfries, UK

2Department of Radiology, Dumfries and Galloway Royal Infirmary, Dumfries, UK ${ }^{3}$ Department of Pathology, Dumfries and Galloway Royal Infirmary, Dumfries, UK

\section{Correspondence to}

Dr Tee Lin Goh;

teelin92@gmail.com

Accepted 15 September 2021

\section{DESCRIPTION}

A 76-year-old woman presented with intermittent colicky left iliac fossa pain, diarrhoea and rectal bleeding. She denied of any weight loss, tenesmus and melaena.

Her medical history included gallstone pancreatitis and hypothyroidism. On examination, she had low-grade fever $\left(37.8^{\circ} \mathrm{C}\right)$ and tenderness in the left iliac fossa. Investigations showed raised lactate $(3.1 \mathrm{mmol} / \mathrm{L})$, white cell count $\left(25.2 \times 10^{9} / \mathrm{L}\right)$ and $C$ reactive protein $(196 \mathrm{mg} / \mathrm{L})$. Stool culture was negative.

Her CT abdomen and pelvis showed diffuse oedema of the wall of descending colon (A) and a large intra-abdominal retroperitoneal fatty lesion with small calcifications in the left iliac fossa extending through inguinal canal (B) on figure 1 .

Intravenous antibiotics and fluids were commenced but she still reported minor rectal bleeding. She remained haemodynamically stable and subsequently underwent flexible sigmoidoscopy which showed inflammation of the descending colon. The histology of descending colon obtained during flexible sigmoidoscopy showed neutrophils infiltrating the surface epithelium and congestion in the lamina propria (figure 2A). This was consistent with ischaemic
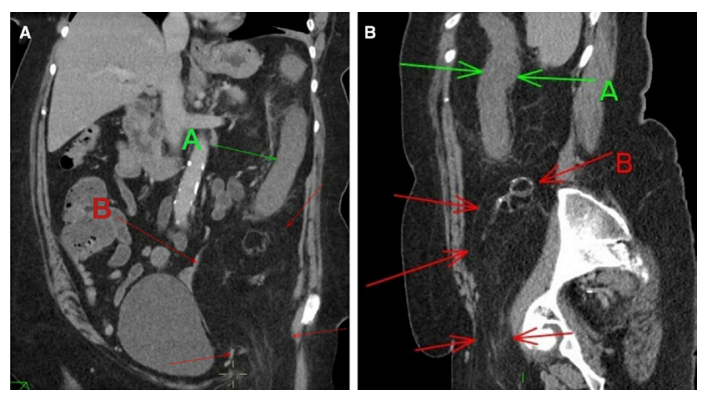

Figure $1 \mathrm{CT}$ abdomen and pelvis (A) coronal view; (B) sagittal view.

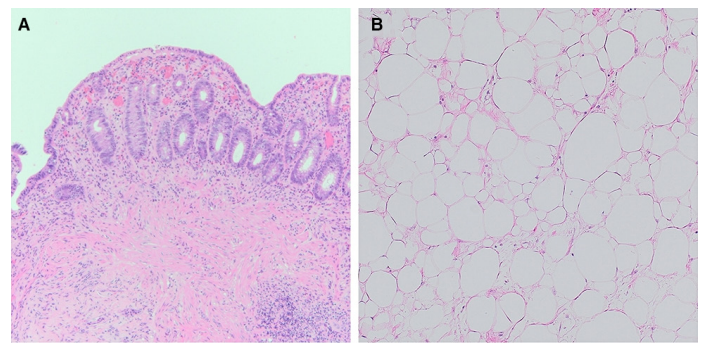

Figure 2 (A) Histology of distal descending colon. (B) Histology of retroperitoneal mass (labelled $B$ on figure $1 A, B)$.

\section{Learning points}

- Soft-tissue sarcomas such as retroperitoneal liposarcomas are rare, but it can cause ischaemic colitis due to compression of the vasculature.

- CT scan should be considered to rule out secondary causes of ischaemic colitis.

colitis secondary to extrinsic compression by the fatty lesion (labelled B on CT abdomen and pelvis).

After discussion at National Sarcoma Multidisciplinary Teams (MDT) meeting, she underwent laparotomy, excision of left retroperitoneal mass of $140 \mathrm{~mm} \times 70 \mathrm{~mm} \times 70 \mathrm{~mm}$, en bloc left salpingo-oophorectomy and excision of thigh component of the mass. The biopsy of the retroperitoneal mass showed viable adipose tissue with scattered stromal nuclear atypia (figure $2 \mathrm{~B}$ ). This was consistent with the diagnosis of a welldifferentiated retroperitoneal liposarcoma stage pT3, causing secondary ischaemic colitis.

Presentation with diarrhoea, colicky abdominal pain and mild rectal bleeding are common in both general medical and surgical admissions. Ischaemic colitis is not an uncommon cause for these presentations with an incidence of 22.9 cases per 100000 person-years. ${ }^{1}$ Ischaemic colitis is commonly related to hypotension and cardiovascular diseases. ${ }^{1}$ However, it is also important for clinicians managing such patients to investigate for secondary causes of ischaemic colitis such as compression of vasculature by tumour, especially when there is not a clear history of hypotension preceding the event.

Soft-tissue sarcomas constitutes $<1 \%$ of all malignancies with liposarcoma accounting for almost $40 \%$ of retroperitoneal sarcomas. ${ }^{2}$ Liposarcoma tends to be asymptomatic at the initial stage but can cause gastrointestinal problems due to compression of adjacent structures. ${ }^{2}$ However, we are unaware of any previous reports of it causing ischaemic colitis. This case highlights the importance of consideration of tumour as the cause of ischaemic colitis.

Contributors TLG wrote the manuscript. TLG and IAM reviewed the literature. JL and RS analysed and provided the radiology and histology images. All authors edited the manuscript.

Funding The authors have not declared a specific grant for this research from any funding agency in the public, commercial or not-for-profit sectors. 
Competing interests None declared.

Patient consent for publication Consent obtained directly from patient(s).

Provenance and peer review Not commissioned; externally peer reviewed.

ORCID iD

Tee Lin Goh http://orcid.org/0000-0001-7266-4752

\section{REFERENCES}

1 Trotter JM, Hunt L, Peter MB. Ischaemic colitis. BMJ 2016;355:i6600

2 Tajudeen M, Dutta S, Bheemanathi S, et al. Pictorial essay on a case of giant retroperitoneal liposarcoma. BMJ Case Rep 2020;13. doi:10.1136/bcr-2020-237607. [Epub ahead of print: 12 Dec 2020].

Copyright 2021 BMJ Publishing Group. All rights reserved. For permission to reuse any of this content visit

https://www.bmj.com/company/products-services/rights-and-licensing/permissions/

BMJ Case Report Fellows may re-use this article for personal use and teaching without any further permission.

Become a Fellow of BMJ Case Reports today and you can:

- Submit as many cases as you like

- Enjoy fast sympathetic peer review and rapid publication of accepted articles

Access all the published articles

Re-use any of the published material for personal use and teaching without further permission

Customer Service

If you have any further queries about your subscription, please contact our customer services team on +44 (0) 2071111105 or via email at support@bmj.com.

Visit casereports.bmj.com for more articles like this and to become a Fellow 